\title{
SUSTAINABLE CITY DEVELOPMENT BY TOURISM OVER CROSS-SECTORAL INDUSTRIES: A CASE STUDY IN CENTRAL SWEDEN
}

\author{
ULRICH SCHMUDDE \\ Mid Sweden University, Sweden
}

\begin{abstract}
The purpose of this paper was to study how sustainable development occurs in a smaller Swedish city through tourism. This study was designed as a qualitative single case study of a smaller city (Östersund) situated in the northern part of central Sweden. Data were collected from semi-structured interviews with regional destination management organisations (DMOs), infrastructure managers, and real estate managers for shopping areas, as well as growth and development managers for the municipality and business entrepreneurs. Data were also collected from secondary sources such as the internet and publications. The results of the study show that different stakeholders play various roles in sustainable development for Östersund. Such development is highly dependent on tourism, mainly summer tourism and events. The famous events have been important in building the brand of the city, and tourists know the area because of them. The conclusions are that sustainable city development needs stakeholders who collaborate or even cooperate across sectors, and particularly those who see their potential crosssectorally. It is not just the tourism industry that contributes to tourism development; shopping and creative business entrepreneurs are vital for the city as well. Sustainable development is also important not just for the tourists but also for the inhabitants of the city. The inhabitants' pride and satisfaction in their city and their word-of-mouth recommendations are the key drivers for the brand of the city, which contributes to its sustainable development.
\end{abstract}

Keywords: sustainable city development, smaller city, branding, events, cross-sectoral collaboration.

\section{INTRODUCTION}

Many cities have cross-sectoral development [1], wherein one sector is the tourism industry. Tourism development in smaller cities situated in peripheral areas plays a significant role in their sustainable development [2], [3]. City tourism in Europe is booming [4]. Particularly big cities benefit, or may even suffer, from this phenomenon (London, Barcelona, Prague, Venice or Dubrovnik - just to mention a few) [4]. At the same time, and relevant for this study, many smaller European cities are driving forces in sustainable development [5]. Moreover, smaller cities situated in peripheral areas have to deal with several challenges to become and remain competitive [6]. These cities search for the right development mainly with the help of the tourism industry [7]. The World Tourism Organization UNWTO [8] clearly exemplified that "tourism is a key driver for socio-economic progress". Particularly, the Scandinavian countries Norway, Sweden, and Denmark are fashionable in the international tourism market [9].

More interest has been growing towards non-touristic industries that contribute to tourism development in smaller cities situated in peripheral areas [1]. In this context, research has not been conducted to any large extent on cross-sectoral industries and their contribution to tourism development in smaller cities situated in these areas. Due to the large global competition of cities, it is essential to have an overall image, a so-called "city branding" that leads to success [10]. Shopping and food tourism, architecture, and culture are popular parts of city tourism. At the same time, the city's branding should "create a community where people will want to live and that will be attractive for the visitors" [10]. In this phenomenon, several industries, in addition to the tourism industry, clearly contribute to city development. 
Fyall et al. [11] stated that, significantly, many studies on destination development have arisen recently, and it is obvious that much attention has been given to the "destination system", especially in the context of market environment competitiveness. On the other hand, there has been less concentration on the importance of collaboration to improve destination competitiveness and to contribute to broader sustainable destination development aims [11]. For instance, Sweden's government [12] has set the political objective to mobilise all actors in the tourism-related system on different territorial entities. The practical side says "in tourism we have to work commonly together to achieve a strong delivery in services" [13], and this point was metaphorically re-confirmed by academic authors: "it would be difficult to extend our co-operation as we are competitors" [14]. Accurately this in [14] mentioned quote mirrors the complexity of the collaboration within a destination, which wants to develop itself with the help of tourism via various involved industries.

Hjalager [15] mentions that various gaps "in the existing literature, including innovation processes in companies and organisations, and the interplay between these processes and the wider governance contexts in which they take place" are important to identify within the complexity of collaborations at a destination [16]. Especially, the interplay between these processes and the wider governance contexts are interesting to examine, since these seem to be connected to delivering services to tourists. The relationship between a tourist destination and an innovation is connected to difficulties in creating synergies between tourism development strategies and potential entrepreneurs [17]. This shows the complexity of the tourism system, but particularly the complexity of the less examined cross-sectoral industries of smaller cities in peripheral areas.

In general, the question of "why" concerning the implementation of new ideas of service providers is often neglected, or even seen as a necessary evil [18]. The purpose of this qualitative study is to identify how tourism is included in the sustainable development of a smaller European city cross-sectorally. In addition, it will clarify the role of the brand in the sustainable development of the city, as well as examining how various stakeholders are involved in the sustainable development process.

The following research questions are raised:

RQ 1: How is tourism included in the sustainable development of a smaller city?

RQ 2: What role does the brand of a smaller city play in sustainable development?

RQ 3: How are different stakeholders involved in the process of sustainable development of a city?

\section{SUSTAINABLE DEVELOPMENT OF A SMALLER CITY}

Sustainable development is a buzzword for the overlapping of a destination's social/cultural, economic, and environmental development [19]. Since the focus of this paper is on a smaller city, it was important to define what constitutes one in a European context. Research was conducted on the definition of sustainable city development, the definition of cross-sectoral industries, big events, the brand's role and those of the various stakeholders involved.

\subsection{Sustainable city development and cross-sectoral industries}

The literature varies in the context of the definition of towns and cities, as well as of the division of small, medium-sized, and large cities. Famighetti [20] and Hartshorn [21] mentioned that in Scandinavia a town begins with a minimum population of 200 inhabitants if the place has non-governmental entities. At the same time, Scandinavian places could be cities if they have a minimum of 200 inhabitants and governmental entities. Due to the variety in the global literature on the topic, it also must be kept in mind that a medium-sized city in 
a European context might be a small city in an Asian context. Giffinger et al. [22] define smaller European cities as under 100,000, medium-sized cities as between 100,000 and 500,000 , and large cities as having more than 500,000 inhabitants. This division makes sense, since the focus in this study is on the northern European territory. Moreover, the name "city" is not only used by an administrative unit; it also denotes a certain population density [23]. With 10,000 to 50,000 inhabitants, one speaks of "towns", and those above 50,000 are called "cities", but this also cannot be generalised; for instance, in the more peripheral areas of Scandinavia a village with more than 200 inhabitants can count as a town or even as a city if it has governmental entities on-site. The current case is a city with a bit more than 50,000 inhabitants and its own governmental entities on-site.

First of all, sustainable city development requires interdisciplinary approaches [24], [25]. Focus has been given by academic authors to the sustainable development of larger cities or metropolises, but not to small cities [26].

In connection to the sustainable development of smaller cities, the research sees the basis of creativity and its contribution towards destination development reflected in Richard Florida's creative class theory, which says that destinations have much more potential in being successful when having a remarkable number of creative people involved [27] and connected. This viewpoint might indicate a connection to the cross-sectoral industries.

"Cross-sectoral industries" simply means in this case that various industries are involved in the development of a city. These industries, which are not just the tourism industry itself, foster tourism development [28]. Meanwhile, research for sustainable development has been conducted on tourism firms that cooperate with other firms in the productive sectors, particularly in cultural activities [28], but it has rarely focused on smaller cities as a whole. This reality outlines the significance of cross-sectoral collaboration and cooperation in achieving tourism supply, and in offering high-quality experiences to tourists, both of which contribute to a city's sustainability (e.g. [29]-[31]).

\subsection{The role of a brand for a smaller city's development}

City branding is mainly defined as an effort by tourism-oriented groups and authorities to market tourist sites [32]. Although it is related to product and service branding, about which much is known, destination branding remains complex, and, hence challenging. Only a few destination brands can be regarded as being really successful [33]. Much research has been conducted on corporate branding theory to build up an understanding of how to brand destinations [34], but corporate branding (e.g. how a city should represent itself) does not provide a solution to many of the difficulties connected to destination branding. A main difficulty is that a city brand represents not only intangible goods and services but also particular places, people and their ideologies (particularly locals, but even tourists) - all of which cannot be simply packaged and sold to tourists [35].

In light of the aforementioned social/cultural difficulty, the perceived identity of residents within a brand representation is a critical issue [36]. This aspect can be simply explained by assuming that the brand projects not just the city to the outside world, but also its inhabitants. Hence, it can influence associated perceptions, such as stereotypes [37]. It seems obvious therefore that the perceived congruity between the residents' personal and suggested brand identity might create positive attitudes and behaviour toward the city's brand [38]. In consumer marketing, this phenomenon is called "self-congruence" and is widely used, but in the context of locals' attitudes towards the city brand it is seldom employed. Thereby, the locals and residents are very important mediators between the city and the tourists, and it is important to identify how residents and small trade operators see the city's branding [39]. 
Research shows that city branding with regard to residents is the major unresolved problem in theory and practise [40].

Schroeder [41] looked beyond the mainstream of destination/resident studies by relating local support for tourism development to the possibility of using locals as ambassadors for their destination of North Dakota. However, this study was more concerned with the destination image than with the brand itself. Henderson [42] made a study of residents' and tourists' awareness of the Singaporean "New Asia" destination brand. The conclusion clearly stated that it is crucial to consult and involve residents in the destination branding process. Unfortunately, no real empirical follow-up has been done in the literature.

The goal of successful inclusive destination branding is to enlist residents' support so that they bring their associations, emotions and creativity to the development of the brand and to a sustainable city development.

\subsection{Events' role in sustainable city development}

Events are a driving force towards tourism development, and they also seem to contribute to a city's development. In particular, large sporting events are used to promote a city as a tourist destination and as a business location [43], as well as such as concerts or various other cultural events.

Even though some big events have been famous and have recurred in the corresponding city for decades, they are still far away from being decommissioned. The question is why? This is not simple to answer, but one thing seems obvious: events are a positive motor in cities, but the contemporary trend in shifting established events from place to place within a city can create tensions between different stakeholders on-site [44]. Moreover, big recurring events are a visitor magnet to a city, since they have been increased in size and intensity, which is a pull-factor towards tourists and visitors [45]. Also in this connection is the competition between cities more than ever increasingly high [45], which means that creativity and innovations play a crucial role in keeping events and making them even more attractive [46]. Also in the context of big events, research has shown that creating social conditions to improve locals' well-being is of high importance, which is a newer determinant [47].

\subsection{The role of stakeholders in the sustainable development of a city}

In the past, planning processes in destinations often relied on an ambiguous simplification of stakeholder theory: they were based on the assumption that all actors and stakeholders pursue the same solutions, with simultaneous engagement and common action, and with the same level of interest in the same problems [48]. Moreover, competitiveness is important, but more crucial is the delivery of the tourism product through correct and successful common work [11]. Beritelli et al.'s study [48] underlines not focusing on all actors, but on those who really commonly contribute towards long-term-oriented development. Organisations that operate within destinations need to change their strategies from "competitive advantage" to "collaborative advantage" [49]. Previous research has focused on the role of destination management organisations (DMOs), but not specifically on the diverse possibilities wherein collaboration can occur at one destination or between destinations, often simultaneously [11].

In outlining various dimensions of destination collaboration in their study, Fyall et al. [11] identified three major categorisations: "organic", "mediated intra-destination" and "mediated intra- and inter-destination". If the collaboration in a destination is organic, then it is independent from a DMO. This stipulation is valid for both cases: organic collaboration within one destination and between two or more destinations. Mediated intra-destination 
means that collaboration within one destination is facilitated by a DMO, whereas mediated intra- and inter-destination means both collaborations in one destination, and between several destinations, are facilitated by a common DMO. It is crucial to differentiate if a DMO is integrated or not. Beritelli et al. [48] even argue that the benefit and role of DMOs toward sustainable stakeholder collaboration is questionable worldwide. This would be shown by longitudinal studies at various levels of territorial entities [50].

One of the main interest groups of a smaller city should be the citizens living there [51]. Not being entirely satisfied with their city is one of the most counterproductive issues for development, particularly for smaller cities [51], since word-of-mouth for the city as well as their creative contribution to its development are crucial [52], [53].

From the Nordic case studies' perspective, it was seen that "the public sector is often a key stakeholder and co-driver in tourism innovation systems" [15]. Behrens [54], for instance, says that the public sector as a key stakeholder should be transferred to an effective stakeholder collaboration as a public-private partnership (PPP). Thereby, various locations also imply different cultural aspects [55], [56]. In general, opinions differ about innovative tourism firms. According to Kohl and Partner [57], for instance, local tourism companies are not real innovation drivers. Often novelties are just copied. Only in the technical sector have innovation impulses been set [57].

\section{METHODOLOGY}

For this single case study, one smaller city in central Sweden with its own governmental entities was chosen. It is a qualitative study with an abductive approach [58]. This pilot study was conducted between March and August 2018, and from June to August 2019. It employed 12 semi-structured interviews with civil servants from the municipality, destination marketing organisations (DMOs), infrastructure companies, tourism companies, and entrepreneurs from agribusiness, with related employees from universities, merchandisers, and the Swedish church. Secondary data were also collected from websites and publications diaries. Data were examined using interpretative analysis involving the construction of themes. The analysis is based on five themes (as described in the second paragraph); namely, reasons for sustainable development of smaller European cities: cross-sectoral industries (1), the role of the brand (2), big events (3), the role of various stakeholders (4), and creativity (5).

The case concerns Östersund, a Swedish university city with ca. 51,000 inhabitants. In this study, the classification of a small[er] city is used, since Östersund's population is far below 100,000 inhabitants, yet has its own governmental entities. The entire municipality consists of ca. 63,500 inhabitants and an entire district surface of $2,517 \mathrm{~km}^{2}$ [59]. It is the capital of the county Jämtland and is situated in the northern part of central Sweden. It is situated by Sweden's fifth largest lake (Lake Storsjön). Östersund is famous as the "Winter City", with several events, such as the biathlon sprint or, in summer, the "Storsjöyran", Sweden's oldest music festival. The city was founded in 1786 by King Gustav III. Jämtland County borders Norway in the west and the counties of Dalarna in the south, Västerbotten in the north, Gävleborg in the south-east and Västernorrland in the east. Jämtland covers $12 \%$ of Sweden's area, but only $1.5 \%$ of Sweden's inhabitants live there. With the exception of Gotland, Jämtland County is the least industrialised county in Sweden, with only $15 \%$ of the population actively working in industry. Fig. 1 gives an overview of Jämtland and the location of its capital Östersund. 


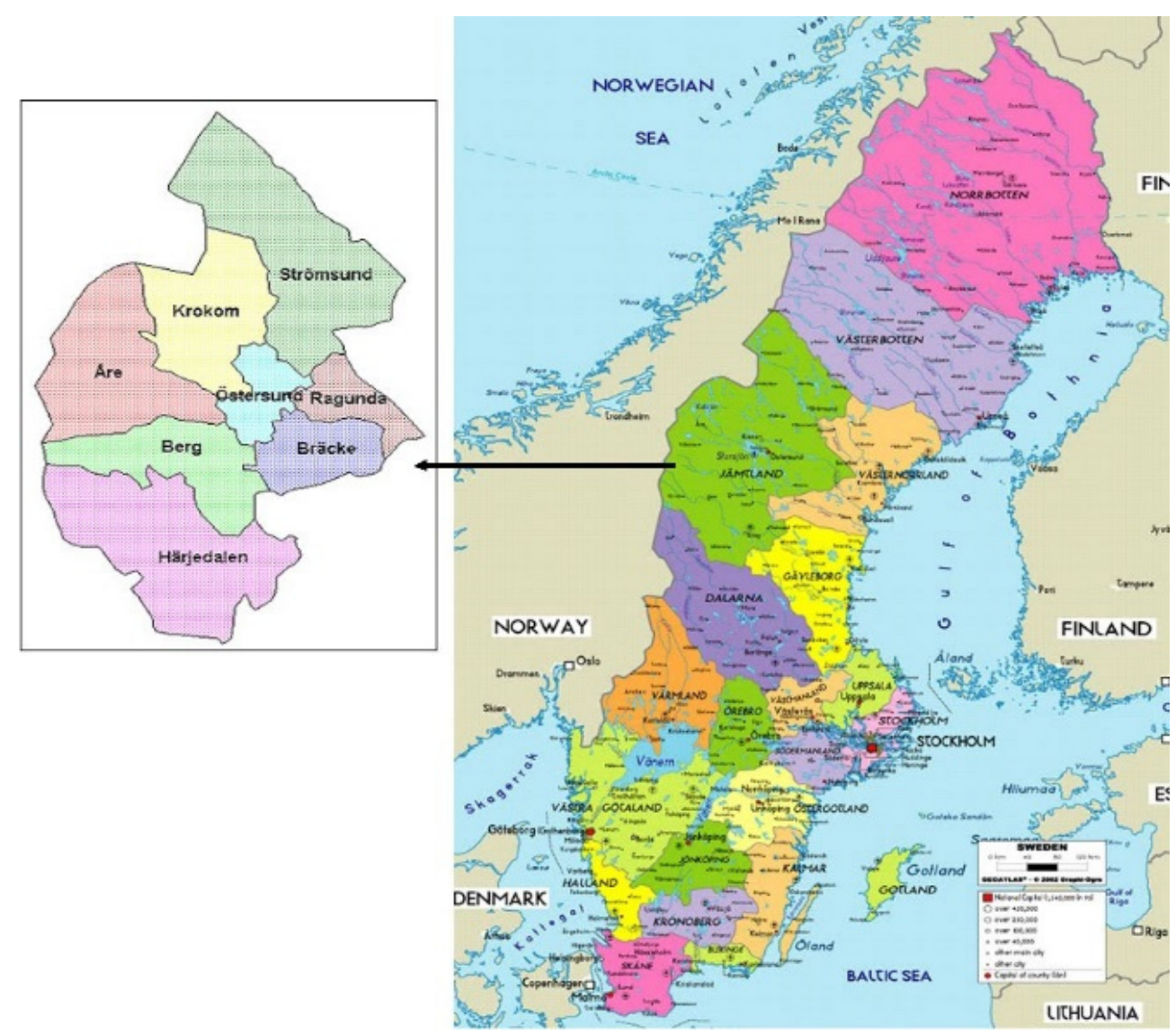

Figure 1: Location of Östersund in Sweden. (Source: http://reregions.blogspot.com/2009/ 10/jamtland-conty-council-sweden.html.)

\section{FINDINGS AND DISCUSSION}

\subsection{Sustainable development of Östersund in a cross-sectoral context}

Östersund is a touristic city but it is also different from mass tourism spots in the region, such as the ski resorts of Åre and Vemdalen, where tourism is the major source of socioeconomic income. Östersund is also a growing city. The tourists comprise various segments: some come to enjoy nature, while others are Norwegian shoppers. Shoppers come from Norway to buy things cheaper than at home, and to enjoy the regional food. Furthermore, conferences and events are a big part of Östersund's tourism services. Therefore, tourism in the city develops in several ways, which is to say that the city has driving forces from several directions related to tourism and commercial life, not just from one traditional tourism direction.

From a sustainable development perspective, tourism drives Östersund and the region's development. While experiencing Östersund, it is possible for tourists to come to the decision: "I want to live here more frequently or even move here". This is a reason for 
attracting tourists, to awake these emotions and wishes. Indirectly, it is also possible and necessary to attract companies to move or to establish and settle their businesses in a region that is highly related to the experience industry. Life quality is a key factor that attracts tourists, but also locals. Of course, tourists contribute to socio-economic development by leaving money and feedback at smaller companies and the food industry (e.g. local cuisine). Moreover, it is important not only to focus on the economic side, but also on the social side: attracting people to drive to Östersund is very important and desirable. Nevertheless, it is important that the locals stay and new people move to the city because of its attractiveness.

Östersund has been nominated as Sweden's best merchandising city in both 2018 and 2019 [60]. Lillänge Köpcentrum is also a shopping area in Östersund. This large merchandising area on the outskirts of the city opened in 2004. Lillänge is not a competitor of the city core, but rather a supplement. It is a shopping motivation for Norwegians and people from the entire county of Jämtland. Merchandising is very important for tourism in Östersund, and the city has a broad field of commercial life. For instance, several local service companies have business contacts with Stockholm and the Mälardalen region, but there are also several locals who live in Östersund but work in the Stockholm region. They are potential mediators between their colleagues and business contacts to talk about Östersund. Moreover, people also come from the Stockholm environs to Östersund to visit friends or family members there. Also, communication with real estate companies is necessary to build new flats and/or to provide updated ones to new residents to their satisfaction. In addition, it is necessary to communicate how more people can be attracted to move to Östersund.

Concerning industrial companies, it is important to say that Östersund was a military city previously. Related to this, there are still large industrial companies there. Concrete collaboration with these companies onsite has not taken place, since they have their own business contacts with the Stockholm region. The DMO Destination Östersund AB (DOAB) could make an analysis of the visitors for those companies to examine to what extent they might need support in relation to touristic activities for their visitors.

There are many facets that lead to tourism development. Developing tourism is called a foundation economy from the city's political side. Hereby the direction is multi-partisan and clear, which is a good goal to set towards sustainable development via tourism. The entire municipality took it as its task to take this direction cross-sectorally into its agenda considerations. The city development project is a part of the long-term oriented goals that are financed by the municipality. For instance, the DOAB, founded in 2014 , is financially supported by the municipality in order to achieve development of the city's core and its commercial life. It consists of 110 shareholders and partners with the goal of developing the city for tourists and for locals. Therefore, the DMO consists of three major pillars: 1 . The city of Östersund, which cares about events and merchandising; 2 . The Östersund Convention Bureau, which is responsible for meetings and congresses; and 3. Visit Östersund, which is responsible for tourism [61].

Since 2017, there have been seasonal direct EasyJet flights from Östersund to London Gatwick and Copenhagen Kastrup Airport, and since 2018 even to Bristol. The airport, DOAB, and Jämtland Härjedalen Turism (JHT) worked with this issue - and they are more actively involved in practical operations. Nevertheless, the municipality communicates with the airport in the context of developing the infrastructure of these new flights, since buses are currently only connected to flights on Scandinavian Airlines (SAS) and Braathens Regional Airlines (BRA). The train traffic could be improved, particularly the night train connections (Stockholm-Östersund v.v.) with the connecting trains from Östersund to Åre. The municipality tries to contribute to a solution for this problem by communicating to "Trafikverket" (the Swedish Transport Administration) and other authorities. On the other 
hand, the municipality works very well together with the "Inlandsbanan" train company, which provides adventurous train packages from Mora in Dalarna to Jokkmokk in Västerbotten [62]. In terms of environmental sustainability, some city buses were tested to drive electrically. In future, it might be possible to drive entirely with electric buses in Östersund and its outskirts. Last but not least, it is important to have a good connection to the world from Frösön Island, where Östersund's airport is situated. From the tourism perspective, it is worthwhile to have a quick connection, since people no longer want to sit and travel the whole time. Concretely, tourists also want to get somewhere quickly without being in transit too long. This is because today everyone has limited time. Moreover, a train needs more time than an airplane, and this can be a challenge. Without this airport, it would not be possible to have this amount of visitors around the year, or even to have a big event there. As mentioned, EasyJet has recently explored heading to Scandinavia. It is very rewarding for the region that English tourists explore the winter destination Åre, but also visit Östersund. The same is valid for the Danish. From a future long-term perspective, it makes sense to analyse if these air routes also contribute towards an increase of German or Dutch tourists, for instance, but especially which new possibilities result in these new air routes. In addition, it is an option to extend the local traffic buses "Stadsbussarna" from the city to the airport such as happens in larger cities. It is useful to think a bit bigger in order to fulfil the picture/function of a city in total. For people it is extremely important to have an easy and comfortable infrastructure in the city after landing and travelling. It is a fact that within the last eight years (from 2010 to 2018) passengers have increased almost $60 \%$ (from 340,000 to $540,000)$ [63], [64]. This success is a result of the airlines opening up this process, but also in the context of simpler accessibility and cheaper prices.

\subsection{The role of the brand for sustainable development of the city}

Östersund is famous for its snowflake heart, which goes back to the winter season 2007/2008, where the first World Championship biathlon took place. For this event, the city wanted one common logotype for itself. After introducing the snowflake heart, research was done on the effects of this brand. It transpired that this snowflake heart has become a positive and famous sign for the city nationally and internationally. Earlier it was the rainbow heart, and during the UNESCO gastronomy conference in 2010 it was the gourmet heart with cutlery. In general, the city keeps the heart as a foundation, and marketers optimise the foundation by transferring it into up-to-date events. Also for the region it is complementary for winter tourism, since Östersund has a larger number of summer tourists who want to visit the city and its surrounded region. The process concerning the snowflake heart during 2017-2018 involved more than 800 inhabitants. The snowflake heart stands for winter tourism, and the discussion was that the city is also a summer city.

\subsection{Events in Östersund}

Several larger events also take place in the city of Östersund. The most famous ones are presented here, but several others also exist. The Storsjöcupen [65] is a large, annual sport eventing for teenagers that has taken place in week 27 for more than 40 years. Its slogan is "proximity, well-being, friendship, good food, equal conditions for girls and boys, and of course a lot of soccer" [65]. It wants to provide teenagers "an international soccer match in a high quality environment of soccer as well as surrounding activities" [65]. For years, the Big Lake Cup (Storsjöcupen) has been so internationally popular that nowadays teenagers from 19 other countries than Sweden come with their relatives. The largest international group 
comes from Norway. These observations confirm that every year during week $27 \sim 40 \%$ of Norwegians are driving cars within the city of Östersund. It is not just the event itself that is affected by the soccer cup: car service companies are also fully booked during this week. The cup affects many other sectors than just the tourism for hotels, camping, restaurants and shopping.

Another famous big event is the Storsjöyran, Sweden's oldest music festival, which has occurred at the end of July every year since 1983 [66]. The number of visitors remains high, but in 2009 Storsjöyran had the most visitors ever on Saturday evening, due to the attraction of singing star Lady Gaga.

The yearly biathlon tempts many Swedish and international tourists to Östersund [67]. In 2019 was the second World Championship in Åre and Östersund, and the first in Östersund in 2008 [67].

Moreover, when the temperature is cold enough, the public Vinterparken (Winter Park) has opened at the Big Lake since 1996 [67], [68]. Here the municipality builds a snow sculpture on the frozen lake, as well as a fireplace with chairs. There are also cross-country and skating tracks on the ice.

Events are therefore a major driving force in visitors' rise of Östersund. Those are a proportion of the airport and infrastructural development. In general, events, dedicative entrepreneurs, tourism, activities, and the reputations of the region, city and villages' are a driving force for this region in relation to this increase in passengers, who prefer easy connections, accessibility, and lower prices. This phenomenon leads to the question: which events do we want to have in the city? For instance, which of these events can contribute to strengthening local merchandising? The municipality wants to strengthen sports events, but not just ones related to ÖFK soccer club or the biathlon. The focus must be on getting people into the city centre in order to be economically beneficial for hotels, restaurants and pubs. It is also thought that it might make sense for merchandisers to prolong their opening hours and make special offers to drive visitors to the city core.

\subsection{The role of stakeholders in the sustainable development process in Östersund}

In Östersund's sustainable development, several stakeholders are involved in making the city creative and attractive for tourists. A major role is played by the citizens of Östersund. Most of them are proud of their city, and this is primarily thanks to successful work, mainly inside but also across the corresponding industries. However, it was mentioned from the entrepreneurial side that the municipality might be even more open to creativity and innovation. At this point it must be considered that not every single stakeholder can be pleased with all of the facets, but the municipality has a collaborative network among various industries. Östersund has been nominated as the "Student City 2018/2019" of Sweden [69], which seems to be a result of cross-sectoral collaboration between Mid Sweden University, the municipality, the merchandisers, the cultural events, and the creativity of various stakeholders on-site.

Since Östersund is a part of the UNESCO creative city network and was nominated as the food capital, one specific item pulling tourists to the city is gastronomy [70]. Three restaurants in the city centre were nominated for "White Guide" awards for best restaurant/café in Sweden [71]. Just around the corner are in the county of Jämtland, local products and beverages of potential interest are processed to nourishments for local customers. This offer makes civils satisfied and are even good sellers to visitors and tourists in the county's capital. This market makes local entrepreneurs creative. One of many good examples is the association of local producers founded in 2018 around Östersund, who come 
every Thursday evening for 30 minutes to the city's market square to sell their products after receiving orders on the association's Facebook site, "Reko-Ring Östersund" [72]. Every member of these associated entrepreneurs can post weekly what they will sell, and the customers within this closed group can order on the corresponding page.

In this context, the level of knowledge of various stakeholders involved plays a role in sustainable development. Clearly and simply said, variety in knowledge is of utmost important in Östersund's sustainable development; for instance, it is crucial that the stakeholders involved understand the contents at the same level. The interrelation between tourism and merchandising, the city core and its relation to tourism, and how tourism influences the city core - all of these interrelated questions are of potential interest to the city's development policy, whereas the experiences in the interrelations mentioned are anchored and conversations are crucial for achieving sustainable socio-economic success. The variety in these interrelations between different stakeholders related to tourism is high: the city has retailers that contribute to a large extent to the commercial development in the city core. Moreover, the municipality owns various properties, which would be very important concerning strategic questions such as development planning. Proper communication and understanding between the municipality and the private owners of properties is necessary when it comes to historic/cultural issues. Also, communications with the "Länsstyrelsen" (county council) are important for such issues, as well as the involvement of private property owners. The branch network is very big, whereas the municipality is a key stakeholder.

It is clear that the municipality is a key stakeholder in the interrelationship PPP. On the other hand, theirs is also a difficult task, since the municipality itself does not create economic development: businesses, people, and locals do. Therefore, it is critical for the municipality to be a communicator in the context of questions such as "what can the municipality do" and "what can businesses and locals do?" Since the municipality as an authority is part of politics, it is vital to collaborate with politicians. It is true that this collaboration generally works well. Since environmental issues are a high priority in Östersund's sustainability policy, it is important to be aware of the natural resources and attractiveness of the municipality. It seems that the latter and the county council function as stakeholders, but this also depends on having the function to observe over-development and keep sustainability as a whole as a consideration.

\section{CONCLUSION}

The study shows that tourism has a significant contribution towards the sustainable development of a smaller European city. Using the example of Östersund, it clearly outlined that not just the tourism industry itself, but also various other industries contribute to tourism development in such a city. This is evidenced, for instance, by merchandising, which shows Norwegians to be the largest foreign tourist group. In short, Östersund's main socioeconomic functions are events, merchandising, and city development, which are all related to tourism. They are different functions, but in collaboration, they are a good symbiosis.

The brand of a smaller city plays a crucial role in its sustainable development, especially in the context of the locals and their satisfaction with their own place of living. It seems obvious that smaller creative entrepreneurs, firms, and organisations/institutions that are not touristic firms should be given more consideration in brand and identity strategies towards the sustainable development of smaller cities, since they mirror their relation to the place with their own brand. Of course, smaller cities should not lose sight of the main contributors, but they should see the bigger picture of innovative creativity on-site. The brand seems to be a driver for development, since Östersund has been mainly a summer city; but with its brand 
introduction as the Winter City, it has become famous in this season as well. This case study has also realised that brands should be renewed after a while, but not arbitrarily.

Big and recurring events play a large role in a smaller city's development, since they are visitor and tourist attractions. This phenomenon is exemplified, for instance, in Östersund's Storsjöyran, which is Sweden's largest and most famous city music festival. The visitor figures have been remained high or even increased, but in 2009 it had the most visitors, due to the attraction of superstar Lady Gaga. This also proves that cities with recurring events cope with creativity and innovation, which Lady Gaga seemed to be at this time.

This qualitative, single case study of Östersund has highlighted the connection between the various industries involved and their stakeholders, but also the role of brands, and creativity towards tourism development as a part of a smaller city's sustainable development. The study shows that various stakeholders involved across sectors are crucial in such development, since they communicate with different channels to their visitors/tourists and they seem to create tourism as much as touristic firms. As stated, satisfied locals are crucial in a smaller city's sustainable development, since they mirror knowledge of their city in a specific and authentic way, which counts for tourists. Moreover, local products and gastronomy as well as their innovative marketing to guests seem to be an increasing and interesting factor in the sustainable development of cities in more peripheral areas.

Since this paper outlined corresponding connections cross-sectorally, it is desirable to obtain more measurable relations from a prospective quantitative or mixed-method study of a sustainable smaller city's development. As a first step, it is recommended to have a further comparative single case study with the major components of local products and gastronomy in relation to brand and identity towards tourism development in a smaller city situated in a rural area in another part of Europe.

\section{REFERENCES}

[1] Valencia, S.C. et al., Adapting the sustainable development goals and the new urban agenda to the city level: Initial reflections from a comparative research project. International Journal of Urban Sustainable Development, 11(1), pp. 4-23, 2019.

[2] Duxbury, N. \& Richards, G., Towards a research agenda for creative tourism: Developments, diversity, and dynamics. A Research Agenda for Creative Tourism, eds N. Duxbury \& G. Richards, pp. 1-14, 2019.

[3] Lawrence, F. \& Rogerson, C.M., Local economic development agencies and peripheral small town development: Evidence from Somerset East, South Africa. Urbani Izziv Supplement, 30, pp. 144-157, 2019.

[4] Maxim, C., Challenges faced by world tourism cities: London's perspective. Current Issues in Tourism, 22(9), pp. 1006-1024, 2019.

[5] Jayne, M., City of Quarters: Urban Villages in the Contemporary City, Routledge, 2017.

[6] Kühn, M., Quo vadis? IRS-forschung zur zukunft von kleinstädten im ländlichen raum. IRS Aktuell Magazin für sozialwissenschaftliche Raumforschung. Kleinstädte in der Peripherie (IRS-Research for the future of smaller cities in the rural context. IRS Current Magazine for Social Science Spatial Research), 79, 2014.

[7] Ali, A. \& Frew, A., Technology innovation and applications in sustainable destination development. Information Technology \& Tourism, 14(4), pp. 265-290, 2014.

[8] The World Tourism Organization, UNWTO Annual Report 2015. www2.unwto.org/sites/all/files/pdf/annual_report_2015_lr.pdf. Accessed on: 17 Jun. 2019. 
[9] Müller, D.K., Hibernating economic decline? Tourism and labour market change in Europe's northern periphery. Tourism and Crisis, eds G. Visser \& S. Ferreira, Routledge, pp. 123-138, 2013.

[10] Herget, J., Petrù, Z. \& Abrhám, J., City branding and its economic impacts on tourism. Economics \& Sociology, 8(1), pp. 119-126, 2015.

[11] Fyall, A., Garrod, B. \& Wang, Y., Destination collaboration: A critical review of theoretical approaches to a multi-dimensional phenomenon. Journal of Destination Marketing \& Management, 1, pp. 10-26, 2012.

[12] Sweden's Government, Sveriges Regeringskansliet, Utredningen Sveriges besöksnäring (The investigation of Sweden's visiting industry), Stockholm, 2016. www.sou.gov.se/besoksnaring/. Accessed on: 4 Aug. 2019.

[13] Gulliksson, F., Founder and CEO of Food in Action. http://foodinaction.se/fiagulliksson-2/. Interviewed on: 20 Aug. 2018.

[14] Von Friedrichs Grängsjö, Y. \& Gummesson, E., Hotel networks and social capital in destination marketing. International Journal of Service Industry Management, 17(1), pp. 58-75, 2006.

[15] Hjalager, A.-M., A review of innovation research in tourism. Tourism Management, 30(1), pp. 1-12, 2010.

[16] Halkier, H., Kozak, M. \& Svensson, B., Introduction, innovation and tourism destination development. European Planning Studies, 22(8), pp. 1547-1550, 2014.

[17] Halkier, H., Kozak, M. \& Svensson, B. INTRODUCTION Innovation and Tourism Destination Development. European Planning Studies, 22(8), pp. 1547-1550, 2014.

[18] Pikkemaat, B., Von der Idee zur Innovation. Ein praktischer Wegweiser für touristische Unternehmen (From the idea to the innovation. A practical guide for touristic firms), 2012. www.standort-tirol.at/data.cfm?vpath=ma-wartbare-inhalte/ downloads-neu/cluster-well/wegweiser-im-tourismus---von-idee-zur-innovation. Accessed on: 22 Jul. 2019.

[19] Andersson, V., Clausen, H.B. \& García, M.V., Transformative change. Diálogos Latinoamericanos, 19(27), pp. 117-126, 2018.

[20] Famighetti, R., The World Almanac and Book Of Facts, St Martins Pr, 1997.

[21] Hartshorn, T.A., Interpreting the City: An Urban Geography, 2nd ed., Wiley: New York, 1992.

[22] Giffinger, R., Fertner, C., Kramar, H. \& Meijers, E., City-ranking of European medium-sized cities. Vienna University of Technology, Vienna and Delft University of Technology, Delft, 2007.

[23] European Union, Cities of tomorrow: Challenges, visions, ways forward, 2011. http://ec.europa.eu/regional_policy/sources/docgener/studies/pdf/citiesoftomorrow/ citiesoftomorrow_final.pdf. Accessed on: 31 Jul. 2019.

[24] Hamdouch, A., Nyseth, T., Demaziere, C., Førde, A., Serrano, J. \& Aarsæther, N., Creative Approaches to Planning and Local Development: Insights from Small and Medium-Sized Towns in Europa, 1st ed., Routledge: New York, 2017.

[25] Servillo, L.A., Atkinson, R., Russo, A.P., Sýkora, L., Demazière, C. \& Hamdouch, A., Town: Small and medium sized towns in their functional territorial context. Final report, 2014.

[26] Bell, D. \& Jayne, M., Small Cities: Urban Experience Beyond the Metropolis, 1st ed., Routledge, 2006.

[27] Thulemark, M. \& Hauge, A., Creativity in the recreational industry: Reconceptualization of the Creative Class theory in a tourism-dominated rural area. Scandinavian Journal of Public Administration, 18(1), pp. 87-105, 2014. 
[28] Mottiar, Z., Quinn, B. \& Ryan, T., Developing cultural tourism through cross-sector co-operation: Evidence from the west of Ireland. School of Hospitality Management and Tourism, 8, 2016.

[29] Viren, P.P., Vogt, C.A., Kline, C., Rummel, A.M. \& Tsao, J., Social network participation and coverage by tourism industry sector. Journal of Destination Marketing \& Management, 4(2), pp. 110-119, 2015.

DOI: 10.1016/j.jdmm.2015.03.004.

[30] Zemla, M., Inter-destination cooperation: Forms, facilitators and inhibitors - The case of Poland. Journal of Destination Marketing \& Management, 3(3), pp. 241-252, 2014.

[31] Novelli, M., Schmitz, B. \& Spencer, T., Networks, clusters and innovation in tourism: A UK experience. Tourism Management, 27(6), pp. 1141-1152, 2006. DOI: 10.1016/j.tourman.2005.11.011.

[32] Papadopoulos, N., Place branding: Evolution, meaning and implications. Place Branding, 1(1), pp. 36-49, 2004. DOI: 10.1057/palgrave.pb.5990003.

[33] Tasci, A.D.A. \& Kozak, M., Destination brands vs. destination images: Do we know what we mean? Journal of Vacation Marketing, 12(4), pp. 299-317, 2006. DOI: $10.1177 / 1356766706067603$.

[34] Knox, S. \& Bickerton, D., The six conventions of corporate branding. European Journal of Marketing, 37(7/8), pp. 998-1016, 2003.

DOI: 10.1108/03090560310477636.

[35] Hankinson, G., Relational network brands: Towards a conceptual model of place brands. Journal of Vacation Marketing, 10(2), pp. 109-121, 2004.

DOI: $10.1177 / 135676670401000202$.

[36] Konečnik Ruzzier, M. \& Petek, N., The importance of diverse stakeholders in place branding: The case of "I feel Slovenia". Anatolia, 23(1), pp. 49-60, 2012.

DOI: $10.1080 / 13032917.2011 .653631$.

[37] Zenker, S. \& Beckmann, S., My place is not your place: Different place brand knowledge by different target groups. Journal of Place Management and Development, 6(1), pp. 6-17, 2013. DOI: 10.1108/17538331311306078.

[38] Sirgy, M.J., Johar, J.S., Samli, A.C. \& Claiborne, C.B., Self-congruity versus functional congruity: Predictors of consumer behavior. Journal of the Academy of Marketing Science, 19(4), pp. 363-375, 1991. DOI: 10.1007/BF02726512.

[39] Morgan, N.J., Pritchard, A. \& Piggott, R., Destination branding and the role of the stakeholders: The case of New Zealand. Journal of Vacation Marketing, 9(3), pp. 285299, 2003. DOI: $10.1177 / 135676670300900307$.

[40] Kalandides, A., Braun, E., Kavaratzis, M. \& Zenker, S., My city, my brand: The different roles of residents in place branding. Journal of Place Management and Development, 6(1), pp. 18-28, 2013. DOI: 10.1108/17538331311306087.

[41] Schroeder, T., The relationship of residents' image of their state as a tourist destination and their support for tourism. Journal of Travel Research, 34(4), pp. 71-73, 1996. DOI: $10.1177 / 004728759603400411$.

[42] Henderson, J.C., Selling places: The new Asia-Singapore brand. Journal of Tourism Studies, 11(1), pp. 36-44, 2000.

[43] Van den Berg, L. \& Braun, E., Sports and City Marketing in European Cities, Routledge: London, 2017. DOI: 10.4324/9781315242576.

[44] Smith, A., Events in the City: Using Public Spaces as Event Venues, Routledge, 2015.

[45] Dornscheidt, W.M., Groth, C. \& Reinhard, H.W., Mega-events. Handbuch Messemanagement, Springer Gabler: Wiesbaden, pp. 965-985, 2017. 
[46] Todd, L., Leask, A. \& Ensor, J., Understanding primary stakeholders' multiple roles in hallmark event tourism management. Tourism Management, 59, pp. 494-509, 2017.

[47] Wise, N., Aquilino, L. \& Armenski, T., Preparing for Matera 2019: Local resident participation in research and perceptions of destination competitiveness. Urban Renewal, Community and Participation, eds J. Clark \& N. Wise, Springer: Cham, pp. 161-180, 2018.

[48] Beritelli, P., Reinhold, S. \& Laesser, C., Prozessorientierung im destinations management (Process orientation in destination management). Marketing Review St. Gallen, 6, pp. 34-46, 2014.

[49] Chen, I.J. \& Paulraj, A., Towards a theory of supply chain management: The constructs and measurements. Journal of Operations Management, 22(2), pp. 119-150, 2004.

[50] Pike, S. \& Page, S., Destination Marketing Organizations and destination marketing: A narrative analysis of the literature. Tourism Management, 41, pp. 202-227, 2014.

[51] Insch, A., Managing residents' satisfaction with city life: Application of importancesatisfaction analysis. Journal of Town \& City Management, 1(2), pp. 164-174, 2010.

[52] Wassler, P., Wang, L. \& Hung, K., Identity and destination branding among residents: How does brand self-congruity influence brand attitude and ambassadorial behavior? International Journal of Tourism Research, 2019.

[53] Taecharungroj, V., City ambassadorship and citizenship behaviours: Modelling resident behaviours that help cities grow. Journal of Place Management and Development, 9(3), pp. 331-350, 2016. DOI: 10.1108/JPMD-03-2016-0009.

[54] Behrens, H., Privatisierung kommunaler Tourismuseinrichtungen im Rahmen der Tourismusentwicklung in Schleswig-Holstein (Privatisation of Municipal Tourism Facilities in the Context of Tourism Development in Schleswig-Holstein), 2006. diplom.de.

[55] Künkel, P., Gerlach, S. \& Frieg, V., Stakeholder-Dialoge erfolgreich gestalten. Kernkompetenzen für erfolgreiche Konsultations- und Kooperationsprozesse (Successfully Shaping Stakeholder Dialogues: Core Competencies for Successful Consultation and Cooperation Processes), Springer Gabler: Wiesbaden, 2016.

[56] Hofstede, G., Cultures and Organizations Software of the Mind Intercultural Cooperation and its Importance for Survival, McGraw-Hill: New York, 1997.

[57] Kohl \& Partner, Wie kommt mehr Innovation in den Tourismus? (How does more innovation come into tourism?), 2016. www.kohl.at/de/magazin/wie-kommt-mehrinnovation-in-den-tourismus/95-124880.html. Accessed on: 17 Jun. 2019.

[58] Järvensivu, T. \& Törnroos, J.Å., Case study research with moderate constructionism: Conceptualization and practical illustration. Industrial Marketing Management, 39(1), pp. 100-108, 2010. DOI: 10.1016/j.indmarman.2008.05.005.

[59] Östersund Municipality, 2019. www.ostersund.se/kommun-och-politik/ kommunfakta.html. Accessed on: 2 Jul. 2019.

[60] Destination Östersund AB, Östersund är Årets Stadskärna 2019! (Östersund is the best city core of 2019!). www.destinationostersund.se/nyheter/2019/5/22/stersund-r-retsstadskrna-2019. Accessed on: 15 Jul. 2019.

[61] Destination Östersund AB (DOAB), 2018. www.destinationostersund.se. Accessed on: 20 Jul. 2018.

[62] Destination Inlandsbanan AB, 2019. https://inlandsbanan.se/en/travel/aboutinlandsbanan. Accessed on: 31 Jul. 2019.

[63] Swedavia AB, 2018. www.swedavia.com/ostersund/?_ga=2.56084073.390856831. 1565047842-1530818355.1563125312. Accessed on: 30 Jun. 2018.

[64] Fahlén, P., CEO of Åre/Östersund Airport. Interviewed on: 5 Jun. 2018. 
[65] Storsjöcupen (The Big Lake Cup), www.storsjocupen.se/. Accessed on: 7 Jul. 2019.

[66] Storsjöyran, https://yran.se/om-yran/. Accessed on: 7 Jul. 2019.

[67] Visit Östersund, www2.visitostersund.se/en/to-do/a118993/try-the-biathlon/ showdetails?filter $=\mathrm{c} \% 3 \mathrm{D} 6288 \% 2 \mathrm{C} 6278 \&$ refcur $=$ EUR. Accessed on: 28 Jul. 2019.

[68] Vinterparken Östersund (Winter Park Östersund), http://vinterparken.se/vinterparkeni-korthet/. Accessed on: 16 Jul. 2019.

[69] Mid Sweden University, Östersund är årets studentstad 2018/2019 (Östersund is Sweden's student city 2018/2019). www.miun.se/kontakt/press/pressmeddelanden/ 2018-4/ostersund-ar-arets-studentstad-20182019/. Accessed on: 22 Jul. 2019.

[70] Östersund Municipality, Unesco: Creative City of Gastronomy. www.ostersund.se/ kommun-och-politik/kvalitet-och-resultat/utmarkelser/unesco-creative-city-ofgastronomy.html. Accessed on: 27 Jul. 2019.

[71] White Guide, Sveriges bästa restauranger och caféer. (Sweden's best restaurants and cafés). www.whiteguide.se/universalsearch?field_restaurant_keyword_value $=\% \mathrm{C} 3$ \%96stersundandtid_2=AllandLandskap=All. Accessed on: 1 Aug. 2019.

[72] Facebook, Reko-Ring Östersund. www.facebook.com/groups/223799768169477/ about/. Accessed on: 1 Aug. 2019. 